\title{
Creativity-Character Element Analysis by Organic Fusion of Creativity and Character"
}

\author{
Younchul Choi ${ }^{1}$, Hyunju Choi ${ }^{2}$, Kyungchul $\mathrm{Kim}^{3}$ and Bookyung Cho ${ }^{4}$ \\ ${ }^{1}$ Dept. Early Childhood Education, Korea National University of Education \\ eekjunechoi@knue.ac.kr \\ ${ }^{2}$ Institute for early child education, Korea National University of Education \\ Corresponding Author: hjchoi1119@knue.ac.kr \\ ${ }^{3}$ Dept. Early Childhood Education, Korea National University of Education \\ kbrian@ ${ }^{4}$ Depue.ac.kr
${ }^{4}$ Early Childhood Education, Korea National University of Education \\ bcho@knue.ac.kr
}

\begin{abstract}
This research aims to extract Creativity-Character Elements by orgenic fusions of Creativity and Character by examining previous researches on the relalionships between creativity and character. Based on previously related researches on the relationship between creativity and character, there are slight differences in opinions, but it appears that they are influencing mutually. Hence, the coherence of lements of creativity and those of characters was endeavored. There were totals of 36 Creativity-Character Elements extracted through this research results. Thistildy attempted organic fusions of Creativity Elements with Character Elements based on the correlation between Creativity and Character. The results of thi. Research would be crucial and fundamental resources for Creativity-Character Education in the educational fields.
\end{abstract}

Keywords: Creativity, Character, Creativity-Character Element, Relationship between creativity and character

\section{Introduction}

The most demanded core qualities of a man living in the society of $21^{\text {st }}$ century are creativity and moral characters. In 2009, the Ministry of Education and Science Technology (MEST) proposed Creativity-Character Education as the strategy for national development. And Creativity-Character Education in fields of education was emphasized through Amendment of Education Curriculum 2009. Creativity-Character Education is the core educational strategy conceiving new values and at the same time, nurturing a man of talent in understanding how to live together [1]. Thus, Creativity-Character Education is thercentral element in training a man of the future society. Insofar, the notion of reativity and character in education were emphasized independently. However, as scholars in the related fields discovered the correlation between Creativity and Character, attempts to combine Creativity and Character were initiated in educational sites. And, Creativity-Character Education became one of educational strategies to raise a creatively competent person [2]. A creatively competent person is a person with righteous characters, moral judgments, and creative thinking abilities. Thus, Creativity-Character Education is a form of futuristic education maintaining crucial notions of Creativity and Character, fusing them organically and fostering both elements simultaneously. As so, the related fields of studies are implementing various researches to fuse creativity and character

\footnotetext{
* This work was supported by the Ministry of Education of the Republic of Korea and the National Research Foundation of Korea (NRF-2015S1A5B8036254)
} 
organically according to shifts in key elements of education. However, the definition for Creativity-Character is still not so clear, and discussions around this is in progress.

According to prior studies [3-4] on the subject of Creativity-Character Education, teachers practicing Creativity-Character Education in the educational fields are aware of the importance of the Creativity-Character Education. However, they also displayed difficulties in educational practices due to no clear definition of Creativity-Character and lack of understanding Creativity-Character Education. Moreover, the shortage in teaching materials for Creativity-Character Education was also identified as a concern in educational practices. Therefore, in order to Creativity-Character Education to be efficiently practiced, Creativity-Character Elements should be presented with clear ideas and concepts in Creativity-Character Education.

First of all, in order to Creativity-Character Education to be properly practiced in educational sites, the term Creativity-Character has to be solidly defined to help related teachers to comprehend. Also, there needs to be researches on analyzing elements drawn from fusing educational elements of Creativity and Character. The Creativity-Character Elements suggested through these processes would help Creativity-Character Education substantially in the educational sites.

As suggested in prior researches, it is true that there is a variety of opinions on the coherence of creativity and character, but at the same time scholars agree that there are common elements that could integrate creativity and character. But in previous studies [5,2] where Creativity-Character Elements were int oduced, only the integration of creativity and character was indicated. And education elements in practices of CreativityCharacter Education were divided and advocated indepencently as Creativity Elements and Character Elements. Ultimately, this d rectly influenced practices of education fields and resulted in confusion and agitation-in Creativity-Character Education. According to these findings, this study will examine the relationship between Creativity and Character and draw upon Creativity-Character Elements by organic fusion of the two. CreativityCharacter Education Elements drawn from this study are expected to be critical and fundamental resources in desighing related programs and evaluation measures, and practices of Creativity-Character Eductation in education fields.

The research question of this study is as follows.

Research Question 1. What are the Creativity-Character Elements resulted in the organic fusion of Creativity and Character?

\section{Relationship betyeen Creativity and Character}

Creativity is an ablyty to make something new and useful [6], it is not a special phenomenon appears in a few geniuses, but a potential ability that everyone possess [7]. Also, the creativity is an ability expressed through the interaction of three systems: individuals, fields and domains. It is a thinking ability of human, which has to be emphasized in individuals and the environment, that is to say, in sociocultural contexts [8]. Also, the creativity is power to bear unique and wonderful though underlining cognitive abilities [9]. As shown above, the notions on the creativity reveal diverse essences depending on positions of scholars. Creativity Elements are also alleged in different ways by each academics.

On the other hand, Character is not an innate personality or a concept of characteristics; but it is learnt human nature that can be changed by deliberate teaching or learning [10]; also it is a concept embracing moral and ethical values, responsibilities, trust, citizenships, etc. like in respect, fairness, care and more [11]. Therefore, Character is one of important elements enabling an individual to manifest his or her abilities, and at the same time it is a key element for communal life. In Republic of Korea, Character Education Improvement Act has been implemented on July 21, 2015 to nourish people with sound and righteous characters. Hereby, the foundation for Character Education in fields of education has been 
established.

Recently, integrated discussions on mutual effects of Creativity and Character are actively in progress [12]. The integration of Creativity and Character is presented in various perspectives by academics. First of all, most commonly taken by scholars studying creativity, the Creativity centralized perspective is a perspective embracing Character Elements within those of Creativity. Cropley [13] extended Creativity Elements within domains of ethicality; Interpreting the creativity within socio-cultural contexts, Cskiszentmihalyi [8] argued that not only individual cognitive qualities, but also qualities of Character and environmental aspects have to be considered for Creativity Elements.

Secondly, there is a perspective encompassing Creativity Elements within Character Elements. Woo [14] insisted on Character Education through Creativity Education by advocating that creativity, especially flexibility, refines and cultivate our character. Jeon [15] adapted creativity within Character Elements; Peterson and Seligman [16] also accepted Creativity, curiosity, open-mindedness, and ardor for study as Character Elements.

Not leaning on one side, third perspective asserts that Creativity and Character are in mutual and inter-woven relationships. For example, in selection and management of clothing and daily goods, both Creativity and Character are important elements; because the Character Elements considering the others and preserying the nature, and the Creativity Elements thinking divergently and solying problems are requested in them. However, there is a claim that an atomic bomb should not be seen as creative outcome. This suggests that the creativity cannot be judged by individual capacity. In an individualistic view, an atomic bomb is creative outcome but in the position of the mankind it may lead to a disaster. Alon those lines of thoughts, the Creativity and Character are in inter-organic relationships where they can be considered on the same page.

Creativity seeks to find somethng exceptional by escaping from things already exist. And character respects and endeavors to kep socio-cultural customs. However, the Creativity and Character are not two completely separate matters, but there are many common constructive elements in them almost allowing them to be seen as two different expressions of the same thing [17]. Hence, Creativity Education and Character Education often understood as incompatible education [18]. The researcher in this study believes that the creativity and character are influencing each other in equal terms and endorses the argument that creativity and the character can co-exist in coherence. However, examining prior researches in this position, Creativity-Character Elements are presented independently from Creativity Elements and Character Elements. In this research, Creativity-Character Elements are drawn from coherence of Creativity Elements and Character Elements.

\section{Search for Elements by Organic Fusion of Creativity and Character}

\subsection{Organic Fusion of Creativity Element and Character Element}

Each academics studying the creativity suggests various Creativity Elements. First of all, Guilford [9] offered divergent thinking (sensibilities on problems, fluency in thoughts, flexibilities in thinking, originality, re-defining, and elaboration) as a Creativity Element. Torrance [7] suggested Creativity Elements in two components of intellectual ability (fluency, flexibility, originality, elaboration, abstraction of titles and resistance on impetuous completion) and affectionate ability (confidence, curiosity, independence in thinking and judging, devotion in work, intuition, not-perceiving things as it is, positive attitude and adventurous spirits). In addition, Korean Educational Development Institute (KEDI) stated that Creativity Elements are bestowed on divergent thinking and convergent thinking. Lee [19] noted cognitive factors, affectionate factors and 
environmental factors in Creativity Elements. Respectively, it seems the reason why each scholars offers different factors for Creativity Elements is, because there are divergent perspectives on the essence of creativity. The same holds the truth in Character Elements depending on scholars.

Josephson [20] presented credibility, respect, responsibility, fairness, consideration and citizenship as factors of Character Elements; Cha [21] identified moral dimension (keyvalue recognition, responsible decision making), social dimension (socio-cognition, affinity) and emotional dimension (self-recognition, self-control) as Character Elements. Furthermore, Korea Institute for Curriculum and Evaluation (KICE) proposed respect, consideration, responsibility, participation, collaboration, empathy, acceptance, conversation and communication skills, problems and conflict-solving-skills and justice as components of Character Elements. There are differences in specific components based on the emphasis of Character Elements.

In order to organically fuse Creativity and Character together, analyses on Creativity Elements and Character Elements has to be conducted first. To achieve this purpose, variously presented Creativity Elements and Character Elements were listed and classified into common domains. Because both the Creativity and Character are consists of qualities required for individuals and qualities required in social relation [22-23,8] this study also separated the two and categorized them as 'elements required in social Kelations' and 'elements required for individuals.' The Creativity Elements and the Character Elements in domains are as follows in $\langle$ Table 1$\rangle$.

\section{Table 1. Creativity Elements and Character Elements in Domains}

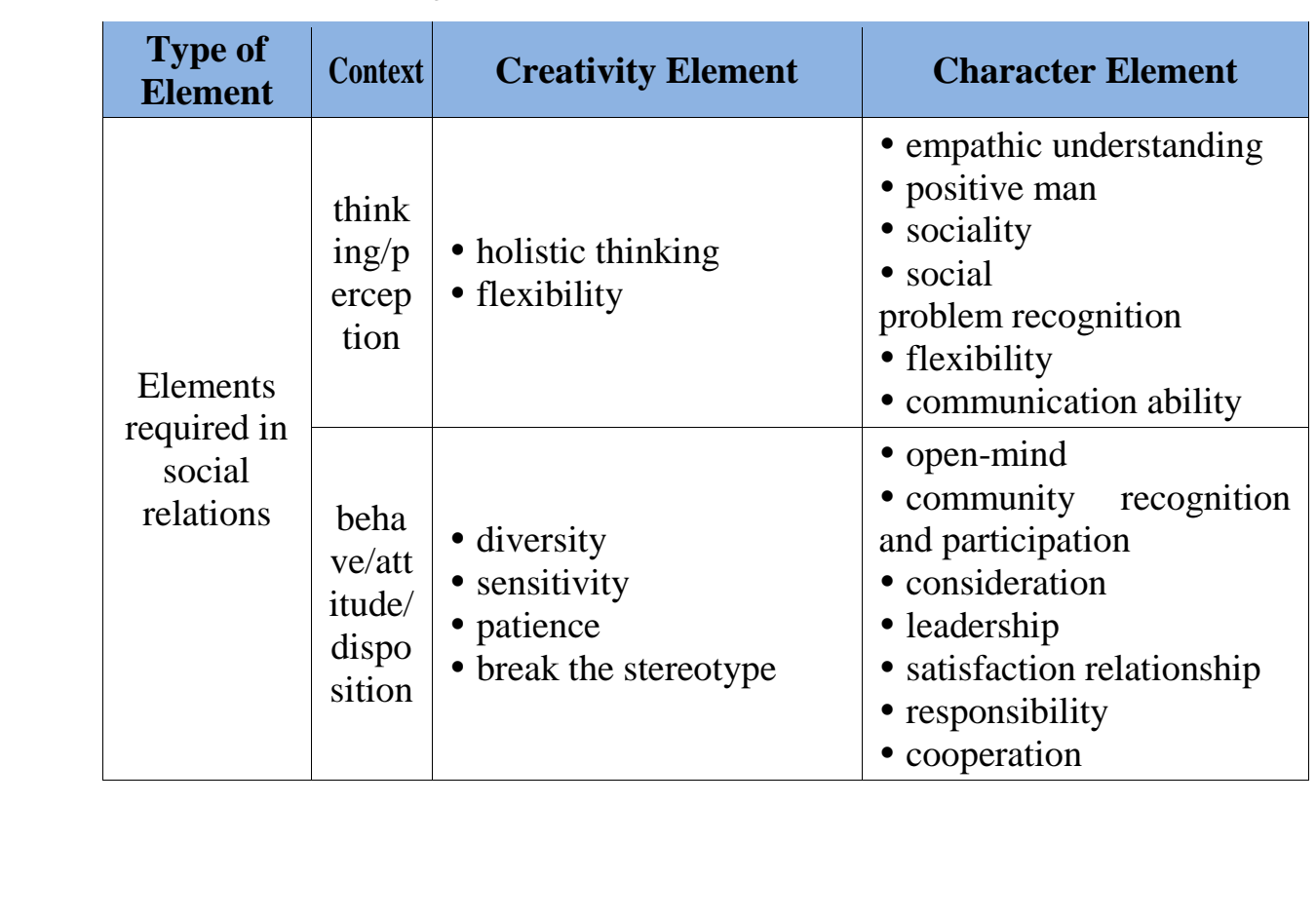




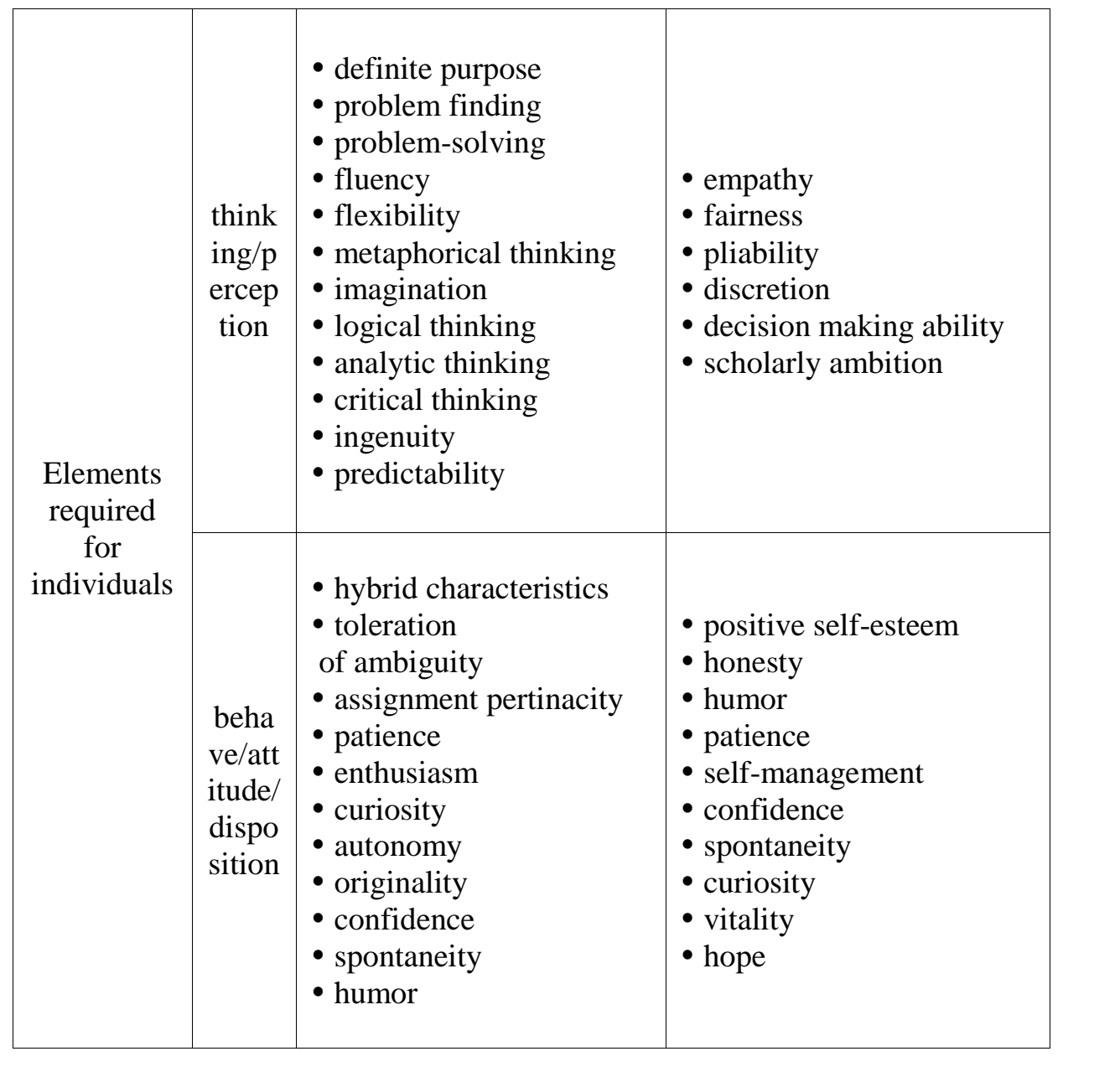

As shown in <Table 1 C C C reativity Elements and Character Elements can be classified as one domain and they atso display the same factors. Peculiarities of these elements can testify relevance of organic fusions of Creativity and Character. Thus, CreativityCharacter Elemênts can be derived from each elements in domains shown in 〈Table 1 $\rangle$.

\subsection{Extracting Creati ity -Character Elements}

Hitherto, the relationship between Creativity and Character were examined through Creativity Elements and Character Elements. The results confirmed that both Creativity and Character were composed of organically fusible elements. Therefore, a Creativity Element and-a Character Element classified as in the same domain can be combined and deduced as one Creativity-Character Element. For example, holistic thinking is a Crea1vity Element that allows unifying concepts of objects in array or opposition and compressing those into a single meaning of thoughts; empathic understanding is a Character Element, in which precisely perceiving and sensibly sympathizing experiences and feelings of the others are encouraged. Concepts of these two factors can be aggregately explained as 'an ability to positively accept thoughts of the others to establish a social situation in a unity.' Thus holistic thinking and empathic understanding can be organically fused into a Creativity-Character Element: 'Ability to Accept Thoughts of the others' [24].

In addition, 'holistic thinking' in Elements Required in Social Relations can be combined with 'empathic Understanding' in Character Elements, resulting in a CreativityCharacter Element of 'Accepting Thought of the Others.' Also, 'Definite Purpose' in Creativity Elements can be integrated with 'Scholarly Ambition' in Character Elements, 
begetting a Creativity-Character Element of 'Concentrating for Definite Purpose.' The Creativity-Character Elements drawn through these processes of analysis are shown in $<$ Table 2>.

Table 2. Creativity-Character Element ${ }^{\dagger}$

\begin{tabular}{|c|c|c|c|}
\hline $\begin{array}{l}\text { Type of } \\
\text { Element }\end{array}$ & Category & $\begin{array}{c}\text { Creativity-Character } \\
\text { Element }\end{array}$ & $\begin{array}{l}\text { Creativity Element/ } \\
\text { Character Element }\end{array}$ \\
\hline \multirow{4}{*}{$\begin{array}{l}\text { Elements } \\
\text { Required } \\
\text { in Social } \\
\text { Relations }\end{array}$} & $\begin{array}{l}\text { Accepting } \\
\text { Social } \\
\text { Problem }\end{array}$ & $\begin{array}{l}\text { - Accepting thoughts } \\
\text { of the others } \\
\text { - Sympathetic } \\
\text { understanding of } \\
\text { social problems }\end{array}$ & $\begin{array}{l}\text { - holistic } \\
\text { thinking/empathic } \\
\text { understanding } \\
\text { - holistic } \\
\text { thinking/social } \\
\text { problem recognition, } \\
\text { empathic } \\
\text { understanding }\end{array}$ \\
\hline & $\begin{array}{c}\text { Creative } \\
\text { Communicati } \\
\text { on }\end{array}$ & $\begin{array}{l}\text { - Flexibility } \\
\text { - Appropriate } \\
\text { communication s }\end{array}$ & $\begin{array}{l}\text { flexibility/flexibility } \\
\text { flexibility/soctality, } \\
\text { communication } \\
\text { ability }\end{array}$ \\
\hline & & $\begin{array}{l}\text { - Consideration of } \\
\text { diversity } \\
\text { - Unification of } \\
\text { oppositional opinions } \\
\text { - Community } \\
\text { recognition and } \\
\text { sensitive response } \\
\text { - Understanding and } \\
\text { sympathizing the } \\
\text { bthers } \\
\text { Interests in new }\end{array}$ & $\begin{array}{l}\text { diversity/considerati } \\
\text { on diversity/open- } \\
\text { mind, leadership } \\
\text { - sensitivity/communi } \\
\text { ty recognition and } \\
\text { participation } \\
\text { - sensitivity/satisfacti } \\
\text { on relationship } \\
\text { - diversity/open-mind }\end{array}$ \\
\hline & $\begin{array}{l}\text { Social } \\
\text { Relations }\end{array}$ & $\begin{array}{l}\text { - Persistent } \\
\text { responsibility } \\
\text { - Patience and } \\
\text { cooperation for the } \\
\text { community } \\
\text { - Leadership } \\
\text { accepting diversity }\end{array}$ & $\begin{array}{l}\text { - patience/responsibil } \\
\text { ity } \\
\text { - patience/community } \\
\text { recognition and } \\
\text { participation, } \\
\text { cooperation } \\
\text { - break the } \\
\text { stereotype/leadership, } \\
\text { responsibility }\end{array}$ \\
\hline $\begin{array}{l}\text { Elements } \\
\text { Required } \\
\quad \text { for } \\
\text { Individua } \\
\quad \text { ls }\end{array}$ & $\begin{array}{l}\text { Valuable } \\
\text { Decision } \\
\text { Making for } \\
\text { Problem } \\
\text { Solving }\end{array}$ & $\begin{array}{l}\text { - Concentrating for } \\
\text { definite purpose } \\
\text { - Recognizing } \\
\text { various problems } \\
\text { - Fair problem- }\end{array}$ & $\begin{array}{l}\text { - definite } \\
\text { purpose/scholarly } \\
\text { ambition } \\
\text { - problem } \\
\text { finding/pliability } \\
\text { - problem- }\end{array}$ \\
\hline
\end{tabular}

\footnotetext{
$\dagger$ Y. C. Choi and H. J. Choi, "Element Analysis for the Creativity-Character Education", Advanced Science and Technology Letters, vol. 127(Education 2016), pp. 261.
} 


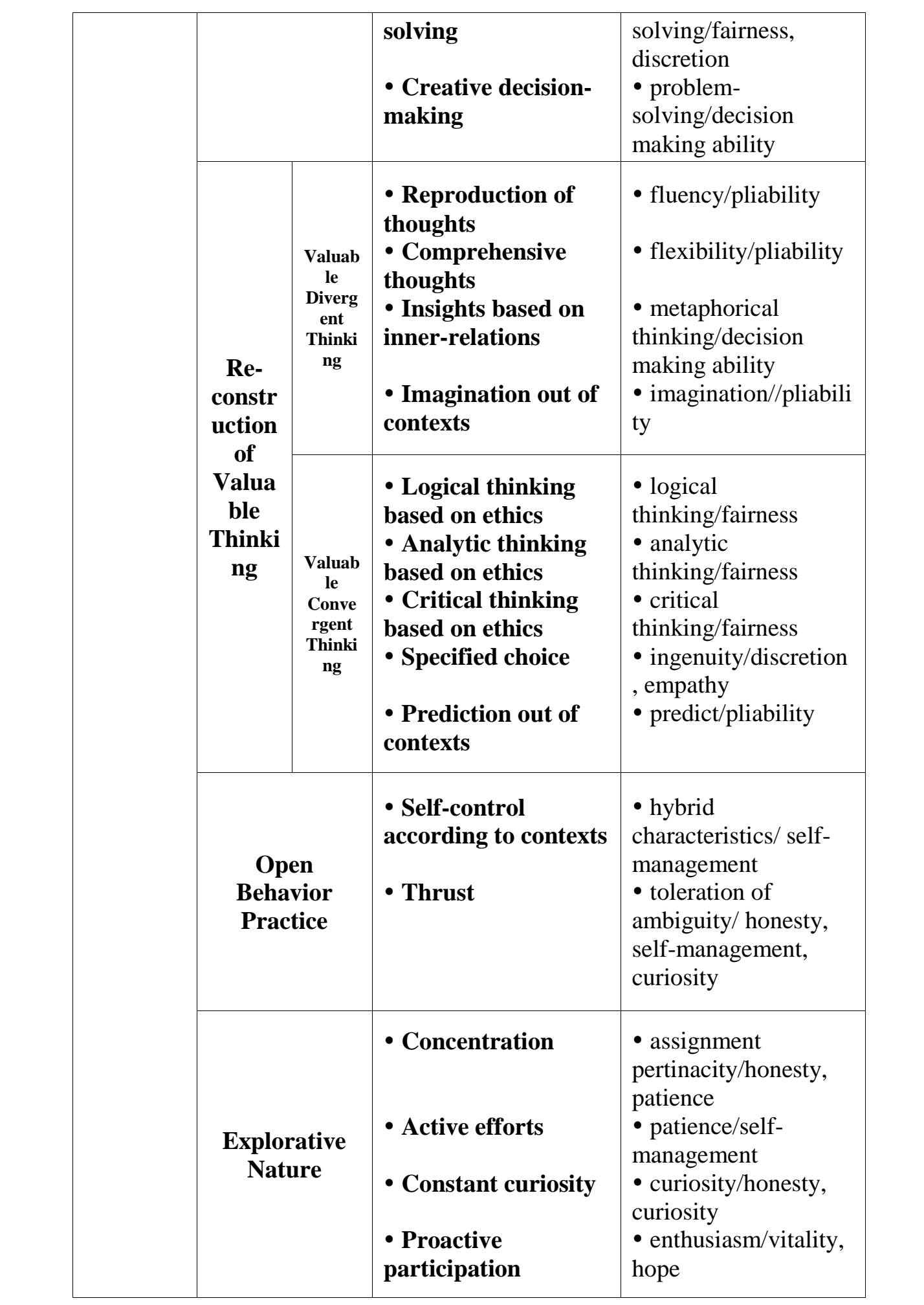




\begin{tabular}{|l|l|l|l|}
\hline & $\begin{array}{l}\bullet \text { Positive } \\
\text { participation } \\
\text { Positive Self- } \\
\text { realization }\end{array}$ & $\begin{array}{l}\bullet \text { autonomy/self- } \\
\text { management, } \\
\text { spontaneity } \\
\bullet \text { originality, } \\
\text { humor/humor } \\
\bullet \text { autonomy/self- } \\
\text { management } \\
\bullet \text { confidence/confiden } \\
\text { ce }\end{array}$ \\
& $\begin{array}{l}\text { regulation } \\
\bullet \text { Confidence } \\
\text { e spontaneity/spontan } \\
\text { eity }\end{array}$ \\
\hline
\end{tabular}

\section{Results and Implications}

This research aimed to identify problems of the Creativity-Character Education in educational sites and isolate the Creativity-Character Elements for the CreativityCharacter Education. To this end, the relationships between Cleativity and Character were inspected through related previous studies. The relationships between the Creativity and Character were suggested in diverse perspectives by various scholars And they affirmed that there were significant correlation between the two. Perspectives on Creativity and Character can be described into largely three aspects. Firstly, a perspective considering Creativity as greater than Character encompasses Character within Creativity Elements $[8,13]$. In contrast, the second perspectiye emcloses Creativity within Character Elements [14-16]. Lastly, the third perspective argues-or equally, balanced relationships between Creativity add Character. This researen has been initiated with an acceptance that Creativity and Character are in mutual relations, Influencing each other in both ways, and that they can be organically fused logether In consequence, the researcher strived to organically fuse Creativity Elements and Character Elements, and drew CreativityCharacter Elements through this process.

The both of Creativily Elements and Character Elements encompass 'Elements Required in Social'Relations' and 'Elements Required for Individuals.' Based on these characteristics, The creativity Elements and Character Elements were classified into a single domain, and this domain was subdivided by factors like 'Thinking/ Cognition' and 'Action/Behavior/Trait.' Fnally categorized Creativity Elements and Character Elements were organically fused Within domains of equal weights and the totals of 36 elements were identified in the results. Details of Creativity-Character Elements were presented in the $\langle$ Table $2>$.

In this research, the possible organic fusions of Creativity and Character are confirmed by assorting Creativity Elements and Character Elements within a single domain. This is once again an important discovery approving the correlation between the Creativity and Character Moreover, Creativity-Character Elements can be extracted for effective practice of Creativity Character Education in educational sites. The Creativity-Character Elements drawn from this study are 'Accepting Social', 'Problem', 'Creative Communication', 'Open Social Relations', 'Responsible Social Relations', 'Valuable Decision Making for Problem Solving', 'Reconstruction of Valuable Thinking', 'Open Behavior Practice', 'Explorative Nature', and 'Positive Self-realization.' And these findings can be applied and utilized as resources for further practices in CreativityCharacter Education.

The implications of this study are: simultaneous measures to educate the Creativity and Character are inspected, and concrete educational elements for Creativity-Character Education are suggested. Based on the results of this research, efforts to systematize the Creativity-Character Education by developing and applying the Creativity-Character 
Education programs, establishing Creativity-Character Assessment Measures, making and distributing teaching materials, and developing programs for teacher-education are demanded in further studies.

\section{References}

[1] Ministry of Education and Science Technology, "Nurturing a Man of Talent in Harmony of Creativity and Consideration", Basic Methods for Character Education, (2009).

[2] Y. L. Moon and I. S. Choi, "Creativity for Nourishing Creative Men Practicing Consideration and Sharing. Studies for Activating Character Education", The Korea Foundation for the Advancement of Science and Creativity, (2010).

[3] H. N. Kim, "Elementary School Teachers' Conception and Management Conditions on Creativity and Character Education", The Graduate School of Ewha Woman's University, (2012).

[4] C. S. Park, "A Study on Application the Moral Curriculum through Creativity \& Character Education", Journal of Korean Elementary Moral Education, vol. 40, (2012), pp. 129-152.

[5] W. D. Kim, "Fundamental Solution for Creativity-Character Education", Science and Technology Policy Institute, Issues \& Policy, (2010), pp. 1-12.

[6] K. W. Jeon and G. S. Kim, "Creativity Education for the Happiest Child in the World", Jung Min Sa, (2012).

[7] E. P. Torrance, "Creativity: Just wanting to know", Pretori, Benedic Books, (1994).

[8] M. Csikszentmihalyi, "Creativity: Flow and the psychology of discovery and invention", New York, Harper Collins, (1996).

[9] J. P. Guilford, "The Nature of Human Intelligence", New York MrGraw-Hill, (1967).

[10] N. S. Cho and H. J. Yun and M. J. Lee and U. G. Cha, New Theories in Ethic-Eucation”, Moon Eum

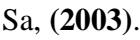

[11] U. S. Department of Education, "Partnerships in character education, state pilot projects", lesson learned, (2008), pp. 1995-2001.

[12] S. J. Eom and J. J. Youn and H. J. Kim and H. S. Lee, "A study on films selection of education content development for promoting pre-service early childhood teacher's creativity and personality using delphi technique", Journal of Digital Convergence, vol. 12, no, 5, (2014), pp. 403-413.

[13] A. J. Cropley, "Creativity in education \& leaning: A guire for teachers and educators", London, Kogan Page, (2001).

[14] J. O. Woo, "Two Big Pillars of 21 Century Education Creativity Education and Character Education", KYOYOOKBOOK, (2010).

[15] J. S. Jeon, "Model Development of Persônality Education for Pre-Service Early Childhood Teacher", Korean Journal of Child Edercation and Care, vol. 13, no. 4, (2013), pp. 305-327.

[16] C. Peterson and M. Seligman, "Character strengths and virtues: A handbook and classification", London, Oxford University Press, (2004).

[17] Y. T. Park, "The Analysis of Meaning of Creativity, Personality, and Creative Personality", Reserch Review, vol 29, no. 1, (2001), pp. 114

[18] J. W. Choi, C. S. Park, K. W. Yeon, Y. K. Min, E. A. Lee, W. S. Jung, J. Y. Seo, D. G. Cha, J. Y. Hur and C. M. Lim, "The problem of character education and alternative approach in korea(creative character education)" Korean Society for Creativity Education, vol. 9, no.. 2, (2009), pp. 89-112.

[19] J. H. Lee, "Development of The program for Improvement of Young Children's Confluent Creativity", Department of Education Graduate School Keimyung University, (2003).

[20] M. S. Josephson, "Making ethical decision: the six pillars of character", Los Angele, CA: Josephson Institute of Ethics, (2002).

[21] S. H. Cha, "Reconstruction of Notions in Character Education", 6 ${ }^{\text {th }}$ Cheongram Education Forum Resource Handout, (2012), pp. 1-33.

[22] IS Choi, "Six Relevant Questions for Better Understanding the Concept of Creativity", Korean Journal of Pychology, vol. 17, no. 1, (1998), pp. 25-47.

23. E. C. Choi and J. J. Park, "The concept and method of creativity and character-emphasized physical education: A view from an integrated approach", The Journal of Curriculum Studies, vol. 29, no. 1, (2011), pp. 209-237.

[24] Y. C. Choi and H. J. Choi, "Element Analysis for the Creativity-Character Education", Advanced Science and Technology Letters, vol. 127, (2016), pp. 260-263. 
International Journal of Multimedia and Ubiquitous Engineering

Vol.11, No.12 (2016)

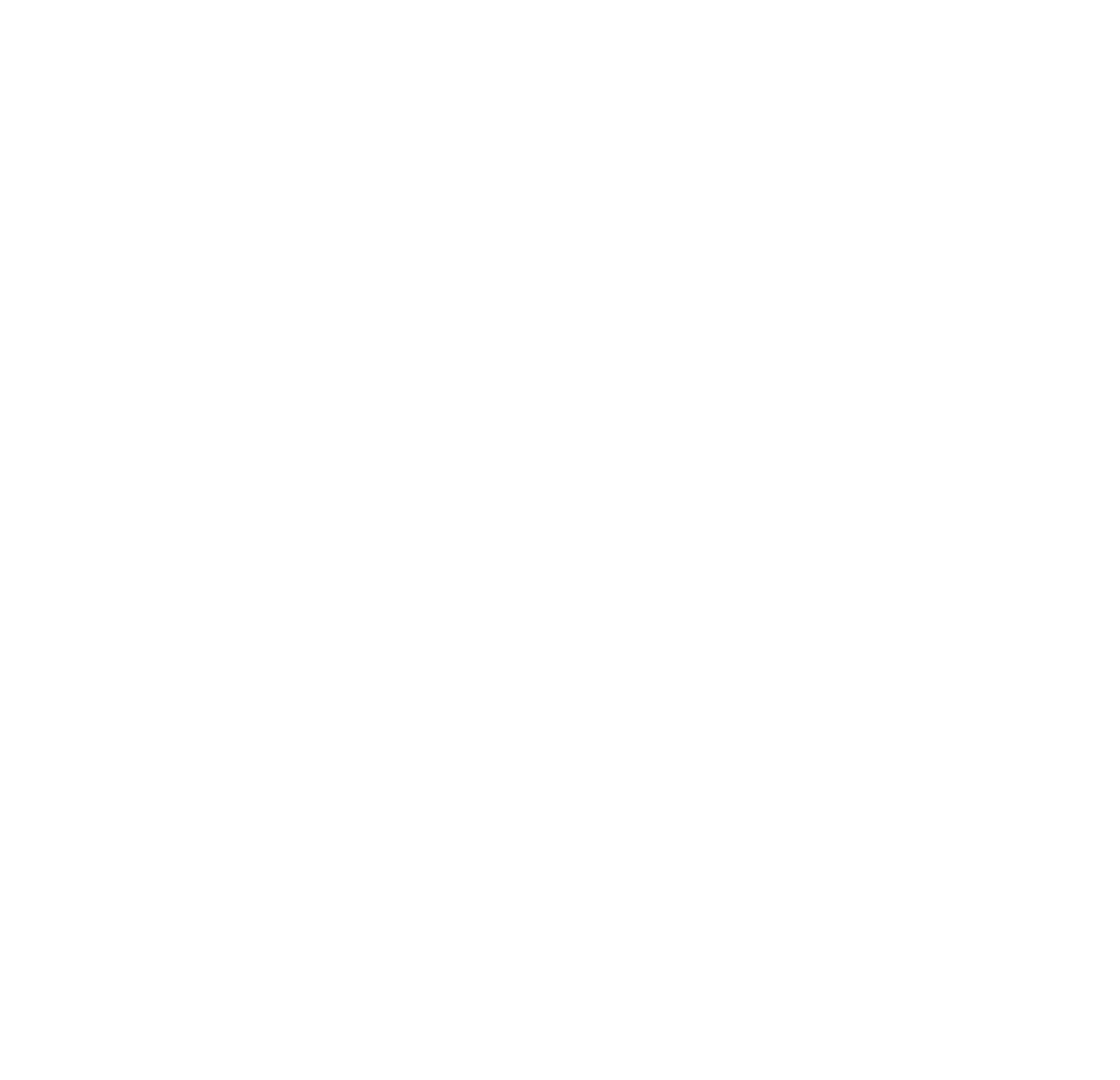

